\title{
Revisiting Mayacaceae Kunth towards to future perspectives in the family
}

\author{
Maria Luiza Silveira de Carvalho ${ }^{1,3}$ \& Anderson F. P. Machado ${ }^{2}$
}

\begin{abstract}
Mayacaceae Kunth is an aquatic plant family that currently comprises a single genus, and four to six accepted species. Most of them are widely distributed in the Neotropics, with the exception of Mayaca baumii Gürke, which is endemic to Africa. This family still encompasses taxonomical problems involving mostly nomenclatural issues and the positioning of the family within the Poales, which remains not definite, though several efforts have being made in this direction. Besides all this, the family also suffers from limited studies with different approaches, such as embryological, palinological, phylogenetic and ecological ones. Considering all this problems, the present work make an overview of Mayacaceae to show the main problems that still surround the family and to indicate some directions for future studies.
\end{abstract}

Key words: Mayaca, monocots, Poales, taxonomic history.

\section{Introduction}

Mayacaceae is a family of monocots, encompassing herbs that inhabit swampy areas, lakes and rivers (Carvalho 2007; Souza \& Lorenzi 2012). The family is distributed within the Neotropics, with species occurring from the south-western United States to Paraguay, with the exception of Mayaca baumii Gürke, which is found only in Africa (Dahlgren et al. 1985). Disregarding this later species, there is no consensus about the real number or even the names that should be considered as valid for the family.

Besides, differences among species have not always been clear, which have lead to taxonomic misinterpretation and the proliferation of several new names (Carvalho 2007). As a result, 22 to 26 names can be found for Mayacaceae in global databases (IPNI 2014; MOBOT 2014), besides the name of the family itself (Horn Af Rantzien 1946; Lourteig 1952, 1968; Carvalho 2007).

Furthermore, there is no consensus regarding the position of the family among monocots. Recently, Mayacaceae is recognized as a distinct and unique family in Poales (APG III 2009) and relationships among this family and its possible sister-groups remain unclear (Givinish et al. 1999; Chase et al. 2000; Stevenson et al. 2000; Michelangeli et al. 2003; Jansen \& Bremer 2004; Linder \& Rudall 2005; Givnish et al. 2010; Bouchenak-Khelladi et al. 2014).

In addition to its nomenclatural and phylogenetic issues, the time of origin and diversification of the family remain unclear (Carvalho 2007). Due to the disjoint pattern of distribution of this family, some authors believe that Mayacaceae might be part of the same branch that originated other groups in Poales (Venturelli \& Bouman 1986; Linder \& Rudall 2005; Carvalho et al. 2009). Some authors hypothesize that this family has its center of genetic diversity in the Brazilian Amazon (Dahlgren et al. 1985; Heywood 1993; Stevenson 1998; Wanderley \& Giullieti 2002), but studies corroborating it are still lacking in the literature.

Considering this scenario, we present an overview of Mayacaceae with the main unsolved issues related to the family systematics and evolutionary history, providing new insights into future studies in this group.

\footnotetext{
${ }^{1}$ Universidade Federal da Bahia, Programa de Pós-graduação em Genética e Biodiversidade, R. Barão de Geremoabo 147, Ondina, 40170-290 Salvador, BA, Brazil.

${ }^{2}$ Universidade Estadual de Feira de Santana, Programa de Pós-graduação em Botânica, Av. Transnordestina s/nº, Novo Horizonte, $44036-900$ Feira de Santana, BA, Brazil.

${ }^{3}$ Author for correspondence: silveiradecarvalho@yahoo.com.br
} 
Recalling a complex taxonomic history

The genus Mayaca was described by Aublet, in 1775, considering only Mayaca fluviatis Aubl. as a species. The etymology of the name is often regarded as a tribute to the "Maiaca River" located in Northern Brazil (see Lourteig 1952; Pott \& Pott 2000). However, this hypothesis seems to be controversial, since the type specimen was collected in the French Guiana in Sinemarí River and furthermore, there is a river in the British Guiana called "Mahaica" that might have inspired Aublet in the genus designation.

Few years later after Aublet's description, two other new genera were described and identified as close to Mayaca, Biaslia Vand. (Vandelli 1788) and Syena Schreb. (Schreber 1789). In spite of the descriptions, these authors did not designate types for the newly described genera, which were in charge of Gmelin (Syena mayaca Gmel. 1791) and Roemer (Biaslia vandellii Roem. 1796). In addition, Willdenow (1797) proposed the inclusion of Mayaca in Syena Schreb., as a new combination Syena fluviatilis (Aubl.) Willd.

Early in the nineteen century, three other authors (Michaux 1803; Shultes 1822; Vellozo 1827) described and synonymized two new species and one genus to Mayaca, respectively: Mayaca aubletii Michx., Syena nuttaliana Schult., and Coletia madida Vell. Almost at the same time, Schott and Endlicher (1832) proposed new combinations to Biaslia vandellii Roem. and Mayaca aubletii Michx., respectively, M. vandellii Schott \& Endl. and Syena aubletii (Michx.) Schott \& Endl. and also described M. michauxii Schott \& Endl. as a new species.

In 1841, Kunth established Mayacaceae as a monogeneric family (Kunth 1841; Lourteig 1952), based on Mayaca fluviatilis Aubl. At the same time, this author considered Biaslia Vand., Coletia Vell. and Syena Schreb. as synonyms of the typical genus (Kunth 1841). A couple of years later, Kunth proposed two additional new species for this family, M. sellowiana Kunth and M. vandellii Kunth, being the latter, a posterior homonymous of $M$. vandellii Schott \& \& Endl. (Kunth 1843).

Even with the recognition of the family, some authors continued to include the taxa previously recognized in different families, such as Xyridaceae (e.g. Grisebach 1866 and Van Tieghem 1898) and Commelinaceae (Hutchinson 1934), creating some taxonomic instability (Lindley 1856; Bentham \& Hooker 1883; Engler 1888; Van Tieghem 1898; Wettstein 1901).
In spite to the controversial position of the species of Mayaca, Seubert (1855) also recognized Mayacaceae as a family with six species, three of them described by this author as new to science (Mayaca vandellii Schott \& Endl., M. aubletii Schott \& Endl., M. kunthii Seub., M. sellowiana Kunth, M. longipes Mart. ex Seub. e M. endlicheri Pöpp ex Seub.). Almost ten years later, two other species were described by Grisebach (1866) and Warming (1867): $M$. wrightii Griseb. and $M$. lagoensis Warm. The first one was later considered as a variety of $M$. fluviatilis (M. fluviatilis var. wrightii (Griseb.) M. Gómez.) by Gómez (1893).

In the early 1900s, Gürke (1902) described a new species, M. baumii Gürke (1902), based on a collection from Angola from Baum Benguela, considering a possible disjunction for the genus. Chodat and Hassel (1903) found a different morphotype for $M$. sellowiana, which according to these authors could be differentiated by the larger stem and by the elongated pedicel that held the flower (Chodat \& Hassel 1903). They described it as a form of $M$. sellowiana f. longipedicellata Chodatt \& Hassl. (1903).

Some years later, another species was described by Hoehne (1937) - M. brasillii Hoehne but later indicated as a "nomen nudum" by Lourteig (1952) for Mayacaceae. At the same time, Gandoger (1920) described two additional species under Mayaca: $M$. caroliniana Gand. and M. longipes Gand., but the latter is a homonym of $M$. longipes Mart.ex. Seub. (Lourteig 1952).

In the first taxonomic revision for Mayacaceae, Lourteig (1952) described the family comprising just five species - M. baumii, M. fluviatilis, $M$. longipes, M. sellowiana, and M. fluviatilis f. kunthii (Seub.) Lourt. According the author, they could be differentiated by the presence of a lobed appendix slot in the anthers. Some years later, Stellfeld (1967) proposed a new combination for Coletia madida: Mayaca madida (Vell.) Stellf. and he rejected $M$. sellowiana, claiming the priority for Coletia madida (Stellfeld 1967). However, this proposal was refuted by Lourteig (1968) and not accepted by the botanical community.

Recently, Venturelli and Bouman (1986) pointed out some embryological features as diagnostic for the family delimitation.

\section{Old problems remain}

In the early twenty-first century, the research involving Mayacaceae focused basically on 
regional and local floras, and among them, the most important ones were the Brazilian (Vandelli 1788; Seubert 1855), Venezuelan (Lourteig 1971), Cuban (Cruz 2001) and the north American floras (Faden 2007). Additionally, other regional works were also important in the family recognition, especially in Brazil (Vellozo 1827; Lourteig 1965; Wanderley 1981; Pedralli 1981; Jaszczerski 1987; Giulietti \& Wanderley 1995; Pedralli 1995; Bove 2001; Wanderley \& Giulietti 2002; Bove 2006) and the United States (Thieret 1975).

Besides them, different studies regarding morphology and anatomy (Uphof 1933; Tomlinson 1969; Stevenson 1998), embryology (Venturelli \& Bouman 1986), physiology (Roberts \& Haynes 1985) and ecology (Souza et al. 2001) were important to provide morphological support to Mayacaceae as a family.

However, studies on the taxonomy of this family are sparse, with just two revisions being published in the past 60 years. The first one was carried out by Lourteig (1952), which recognized four species for the family (Mayaca baumii Gürke, M. fluviatilis Aubl., M. longipes Mart. ex Seub. and M. sellowiana Kunth), besides the designation of several synonyms. Morphological and anatomic characters were not well explored by the author which provided subsides for a later revision, where previous taxonomic and nomenclatural decisions were contested (Carvalho 2007) (see Table 1).

Anatomical characters of the anthers supported, for example, the reestablishment of a name (Mayaca kunthii Seub.) published in 1855 by Seubert (Carvalho 2007; Carvalho et al. 2009). Besides this later and M. baumii, tree other Neotropical species (M. fluviatilis, M. longipes and
M. sellowiana) were recognized for the family by Carvalho (2007), considering the type of anther dehiscence (slit or pore), the arrangement of the flowers (solitary or umbellate inflorescence) and the colouring of the petals (white or pink).

However, many taxonomic decisions could not be validated by Carvalho (2007) due to the lack of nomenclatural types and protologues available for some species.

The systematic position of Mayacaceae among the Poales remains unresolved and these problems seem to have arisen concurrently with the history of the family. As mentioned above, during a long time Mayaca was placed in Xyridaceae (Grisebach 1866; Van Tieghem 1989) or Commelinaceae (Hutchinson 1934). It took a long time before the placement of the family as a distinct group sustained by embryological characters related to the anthers, ovules, endosperm and seeds (Venturelli \& Bouman 1986; Carvalho et al. 2009), corroborating Kunth (1843). Additional characters such as the axillary isolated flowers associated with a membranous bract; endosperm containing proteins and aeriferous channels in the stem provided morphological support for the family (Carvalho 2007; Souza \& Lorenzi 2012; Stevens 2014).

Nowadays, the family is placed within 17 other families in the order Poales (APG III 2009) and supported by molecular (Givinish et al. 1999; Chase et al. 2000; Stevenson et al. 2000; Michelangeli et al. 2003; Jansen \& Bremer 2004; Linder \& Rudall 2005; Givnish et al. 2010; Bouchenak-Khelladi et al. 2014), and morphological studies (Dahlgren \& Clifford 1982; Venturelli \& Bouman 1986; Stevenson 1998;

Table 1 - Comparison of Mayaca accepted names in recent publications.

\begin{tabular}{|c|c|c|c|c|}
\hline Taxa & $\begin{array}{c}\text { Lourteig } \\
\text { (1952) }\end{array}$ & $\begin{array}{c}\text { Cruz } \\
(2001) \\
\end{array}$ & $\begin{array}{c}\text { Carvalho } \\
(2007) \\
\end{array}$ & $\begin{array}{c}\text { The Plant list } \\
\text { (2014) }\end{array}$ \\
\hline M. aubletii & $=$ M. fluviatilis & Accepted & $=$ M. fluviatilis & $=M$. fluviatilis \\
\hline M. baumii & Accepted & Accepted & Accepted & Accepted \\
\hline M. fluviatilis & Accepted & Accepted & Accepted & Accepted \\
\hline M. kunthii & $\equiv M$. fluviatilis f. kunthii & Not reported & Accepted & Accepted \\
\hline M. longipes & Accepted & Accepted & Accepted & Accepted \\
\hline M. madida & $=$ M. sellowiana & Accepted & $=$ M. sellowiana & Accepted \\
\hline M. sellowiana & Accepted & Accepted & Accepted & $=M$. madida \\
\hline M. wrigthii & $=$ M. fluviatilis & $=M$. fluviatilis & $=M$. fluviatilis & Accepted \\
\hline
\end{tabular}


Furness \& Rudall 1998; 1999; Rudall \& Sajo 1999; Carvalho 2009; Oriani \& Scatena 2012, 2014).

However, there is no consensus about which of them is sister-group to Mayacaceae (Givinish et al. 1999; Chase et al. 2000; Stevenson et al. 2000; Michelangeli et al. 2003; Jansen \& Bremer 2004; Linder \& Rudall 2005; Givnish et al. 2010; Bouchenak-Khelladi et al. 2014). According to some authors, this may be due to the nature of the molecular analysis performed (Givinish et al. 1999; Chase et al. 2000; Stevenson et al. 2000; Michelangeli et al. 2003; Jansen \& Bremer 2004; Linder \& Rudall 2005; Givnish et al. 2010; Bouchenak-Khelladi et al. 2014).

Another explanation given by Bremer (2002) is that disregarding the taxa included in the analysis, Mayacaceae tends to be associated to Xyridaceae and Eriocaulaceae. The idea of Mayacaceae be part of the xyrid clade has been sustained by different authors along the years (Linder e Rudall 2005; Saarela et al. 2007; Givnish et al.2010; Stevens 2014). Jansen \& Bremer (2004) for example indicated that Mayacaceae is placed in the same clade along with Eriocaulaceae and Xyridaceae, ands as sister group of Hydatelaceae and Cyperaceae. Despite the exclusion of Hydatelaceae from the Monocots (Saarela et al. 2007), this analysis could be influenced, according to these authors, by the phenomenon of the long branch attraction (Jansen $\&$ Bremer 2004), which indicates that the molecular analysis could be affected by other factors depending on the sampling used.

In another study, a different scenario was found for Mayacaceae, which was primarily included in the Cyperid clade and related to Cyperaceae, Juncaceae, Mayacaceae, Rapataceae and Thurniaceae (Bouchenak-Khelladi et al. 2014). However, these relationships were weaklysupported, indicating that further studies should be performed.

Morphological studies have also been extensively used to subside within Mayacaceae and its sister-groups (Dahlgren \& Clifford 1982; Venturelli \& Bouman 1986; Stevenson 1998; Furness \& Rudall 1998; 1999; Rudall \& Sajo 1999; Carvalho 2009; Oriani \& Scatena 2012 , 2014). This kind of approach was also used to support phylogenetic relationships, but unfortunately, depending on the character selected different topologies were recovered, with no consensus. Characters linked to the stamens, ovules, endosperm, and to the seeds have been suggested (Dahlgren \& Clifford 1982; Venturelli \& Bouman 1986 Stevenson 1998; Rudall \& Sajo 1999; Carvalho et al. 2009; Oriani \& Scatena 2014) as some connection between Mayacaceae and Eriocaulaceae and Xyridaceae.

Meanwhile other characters, such as the development of the anthers wall and the reduction of fertile stamens in the inner whorl, would respectively withdraw Mayacaceae from these families (Furness \& Rudall 1998; 1999) and place it along Juncaceae and Cyperaceae (Oriani \& Scatena 2012).

This examples show that both molecular and morphological evidence might be used to indicate new perspectives for Mayacaceae. Nevertheless, the amount of information is still insufficient to solve many problems that involve the family, and therefore new directions should be taken in order to improve its knowledge.

\section{Future perspectives}

According to that, we can make some basic assumptions: despite the last advances made in Mayacaceae, little is known about this shadowy family. The morphology has been provided with important subside to differentiate internal and interfamilial relationships among the family. In addition, different studies have tried to trace its evolutionary history. Here we present some perspectives to guide future studies in Mayacaceae:

1. Classical Taxonomy: As a prior study, we consider imperative the compilation of all the data available for the family in a substantial revision work, in order to conclude the studies initiated by Carvalho (2007) and solve the remaining nomenclatural and taxonomic problems. The type of the African species M. baumii, the most rare and peculiar species of the family was recently found, examined and identified.

2. Embriology and palinology: Despite all the studies published, a special attention should be paid to the developmental of the floral organs, due to their importance in the taxonomy and role in the evolution of the group. To complement that, new studies should involve the analysis of pollen grains in Mayacaceae and possible related families based on its use for low and higher groups, especially in Monocot (Metcalfe 1952).

3. Molecular phylogeny: Additionally to the studies cited above, we consider that a phylogenetic study with a larger sampling of Mayacaceae and its allies, including morphotypes along its 
geographic distribution will be crucial. Improving sampling could provide a better resolution for the group and also elucidate some biogeographical questions involving the family. Nevertheless, phylogeographic studies are also welcome in order to give subsides for the understanding of species complexes, considering that their wide distribution throughout the Neotropics and the relict in Africa (M. baumii) could be related to peculiar events of dispersal and vicariance around the globe.

4. Ecology: Finally, ecological studies involving pollination, dispersion and germination are fundamental to understand the evolutionary history of the family. Because of its aquatic habit,its species might have particular ways to promote or avoid cross and self-pollination, to disperse the seeds through the water and germinate its seeds in optimal climate. Its could elucidate patterns of distribution in the family and to give subsides to understand which evolutionary paths this group might have taken.

\section{Acknowledgments}

The authors thank Coordenação de Aperfeiçoamento de Pessoal de Nível Superior (CAPES) for the post doc fellowship grant to MLSC, Fundação de Amparo à Pesquisa do Estado da Bahia (FAPESB) for the Phd fellowship grant to AFPM, and to Marcos C. Dórea for the assistance with type images from Kew Herbarium, as part of the Reflora Project.

\section{References}

APG III. 2009. An update of the Angiosperm Phylogeny Group classification for the orders and families of flowering plants: APG III. Botanical Journal of the Linnean Society 161: 105-121.

Aublet, F. 1775. Histoire des plantes de la Guiane Françoise. P.-F. Didot, London. 621p.

Bouchenak-Khelladi, Y.; Muasya, A.M. \& Linder, H.P. 2014. A revised evolutionary history of Poales: Origins and diversification. Botanical Journal of the Linnean Society 165: 4-16.

Bove, C.P. 2001. Mayacaceae. In: Costa, A. \& Dias, I.C.A. (eds.). Flora do Parque Nacional da Restinga de Jurubatiba e Arredores, Rio de Janeiro, Brasil: Angiospermas, Pteridófitas, Algas Continentais. Editora do Museu Nacional, Rio de Janeiro. 93p.

Bremer, K. 2002. Gondwanan evolution of the grass alliance of families. Evolution 56: 1374-1387.

Carvalho, M.L.S. 2007. Estudos taxonômicos em Mayacaceae Kunth. Dissertação de Mestrado. Universidade Estadual Paulista Júlio de Mesquita Filho, Rio Claro. 64p.
Carvalho, M.L.S.; Giulietti, A.M. \& Wanderley, M.G.L. 2011. Mayacaceae. In: Wanderley, M.G.L. et al. Checklist of Spermatophyta of the São Paulo State, Brazil. Biota Neotropica 11: 297.

Chase, M.W.; Soltis, D.E.; Soltis, P.S.; Rudall, P.J.; Fay, M.F.; Hahn, W.H.; Sullivan, S.; Joseph, J.; Givinish, T.; Sytsma, K.J. \& Pires, J.C. 2000. Higher-level systematics of the monocotyledons: An assessment of current knowledge and a new classification. In: Wilson, K. \& Morrison, D. Monocots: Systematics and Evolution. CSIRO, Melbourne. Pp. 3-16.

Chodat, R.H. \& Hassler, E. 1903. Plantae Hasslerianae soit énumeration des plantes recoltées au Paraguay par le dr. Émile Hassler, d`Aarau (Suisse) et déterminées par le prof. dr. R. Chodat avec l'aide de plusieurs collaborateurs. Bulletin Herbier Boissier 3: 1033.

Cruz, A. 2001. Las Mayacaceae de Cuba. Anales del Jardín Botánico de Madrid 58: 325-329.

Dahlgren, R.M.T. \& Clifford, H.T. 1982. The monocotyledons: a comparative study. Academic Press, London. 378p.

Dahlgren, R; Rasmussen, F.N. \& Yeo, P.F. 1985. The Families of the Monocotyledons. Springer-Verlag, Berlin. 520p.

Engler, A. 1888. Mayacaceae. In: Engler, A. Die natürlichen Planzenfamilien. 2: 16-18, fig. 6.

Faden, R. Mayacaceae. In: Flora of North America. Available at $<\mathrm{http}$ ://www.eFloras.org $>$. Access on 10 september 2014.

Gandoger, M. 1920. Sertum plantarum novarum. Bulletin de la Société Botanique de France 66: 286-307.

Giulietti, A.M. \& Wanderley, M.G.L. 1995. Mayacaceae. In: Stannard, B. Flora of the Pico das Almas. Kew Gardens, Surrey. Pp. 724-725.

Givnish, T.; Ames, M.; McNeal, J.; McKain, M.; Steele, P.; de Pamphilis, C.; Graham, S.; Pires, J.; Stevenson, D.; Zomlefer, W.; Briggs, B.; Duvall, M.; Moore, M.; Heaney, J.; Soltis, D.; Soltis, P.; Thiele, K. \& Leebens-Mack, J. 2010. Assembling the tree of the monocotyledons: Plastome sequence phylogeny and evolution of Poales. Annals of the Missouri Botanical Garden 97: 584-616.

Gmelin. J.F. 1791. Caroli à Linné, Systema naturae per regna tria naturae, secundum classes, ordines, genera, species, cum characteribus, differentiis. Vol. 2. Georg Emanuel Beer, Leipzig. 121p.

Gómez, M.1893. Noctulae Botanica Sistematica. Printed by the Author. $52 \mathrm{p}$.

Grisebach, A. 1866. Catalogus Plantarum Cubensium. Vols. 1-4. Wilhelm Engelman, Leipzig. 301p.

Gürke, M. 1901. Eine Neue Mayaca - Art aus Africa. Botanische Jahrbücher für Systematik 31: 1-2.

Heywood, V.D. 1993. Flowering plants of the world. Oxford University Press, Oxford. 336p.

Hoehne, F.C. 1937. Resenha Histórica da Secção Botânica Agronômica do Instituto Biológico de 
São Paulo. Secretaria de Agricultura, Indústria e Comércio, São Paulo. Pp. 136-156.

Horn, A.F. \& Rantzien, H. 1946. Notes on the Mayacaceae of the Regnellian Herbarium in the Riksmuseum, Svensk Botanisk Tidskrift 40: 405-424.

Hutchinson, J. 1934. The families of flowering plants II. Monocotyledons. Mac Millan \& Co., London. 610p.

IPNI. The International Plant Names Index. Available at $<$ http://www.ipni.org/index.html $>$. Access on 25 september 2014.

Jansen, T. \& Bremer, K. 2004. The age of major monocot groups inferred from $800+$ rbcL sequences. Botanical Journal of the Linnean Society 146: 385-398.

Jaszczerski, J.C. 1987. Mayacaceae Kunth do Estado do Paraná, Brasil. Estudos de Biologia 27: 3-14.

Kunth, C.S. 1841. Über Mayaca Aubl. Abhandlunge der Preussischen Akademie der Wissenschaften. Physikalisch-Mathematische Classe 39: 1-4.

Kunth, K.S. 1843. Mayacaceae. In: Kunth, K.S. (ed.). Enumeratio Plantarum Omnium Hucusque Cognitarum, Secundum Familias Naturales Disposita, Adjectis Characteribus, Differntiis et Synonymis. Stutgardiae et Tubingae. Vol. 4. J.G. Cottae, Stuttgart and Tübingen. 32p.

Linder, H.P. \& Rudall, P.J. 2005. Evolutionary history of Poales. Annual Review of Ecology, Evolution and Systematics 36: 107-124.

Lourteig, A. 1952. Mayacaceae. Notulula Systematica 14: 234-248.

Lourteig, A. 1968. Sur Mayaca sellowiana (Mayacaceae). Taxon 17: 742-743.

Lourteig, A. 1971. Mayacaceae. In: Lasser, T. Flora de Venezuela. Vol. 3. Artegrafia, Caracas. Pp. 1-7.

Metcalfe, C.R. 1952. Monocotyledons for Anatomical Investigation. Taxon 1: 127-132

Michaux, A. 1803. Mayacaceae In: Michaux, A. (ed.). Flora boreali-americana: sistens caracteres plantarum quas in America septentrionali collegit et detexit Andreas Michaux. Vol. 1. Parisiis et Argentorati, Levrault. Pp. 26.

Michelangeli, F.A.; Davis, J.I. \& Stevenson, D.W. 2003. Phylogenetic relationships among Poaceae and related families as inferred from morphology, inversions in the plastid genome, and sequence data from the mitochondrial and plastid genomes. American Journal of Botany 90: 93-106.

Monteiro, R.F. \& Carvalho, M.L.S. 2010. Mayacaceae. In: Lista de Espécies da Flora do Brasil. Jardim Botânico do Rio de Janeiro. Available at <http:// reflora.jbrj.gov.br/jabot/floradobrasil/FB160>. Access on 30 september 2014.

Pedralli, G. 1981. A família Mayacaceae Kunth no Rio Grande do Sul, Brasil. Iheringia 28: 47-54.

Pedralli, G. 1995. Flora da Serra do Cipó. Boletim de Botânica da Universidade de São Paulo 14: 235-239.
Pott, V.J. \& Pott, A. 2000. Plantas Aquáticas do Pantanal. Embrapa, Brasília. 404p.

Roberts, M.L. \& Haynes, R.R. 1985. Flavonoids of Mayaca fluviatilis (Mayacaceae). Phytochemistry 24: 3077-3078.

Roemer, J.J. 1796. Scriptores de planus hispanicis, lusitanicis,brasiliensibus, adornavit et recudi curavit. Vol. 72. Schäferischen Buchhandlung, Leipzig. 184p.

Rudall, P.J. \& Sajo, M.G. 1999. Systematic position of Xyris: flower and seed anatomy. International Journal of Plant Sciences 160: 795-808.

Rusby, H.H. 1927. Description of new Genera and Species of plants collected on the Mulford Biological exploration of the Amazon Valley 19211922. Memoirs of the New York Botanical Garden 7: 205-387.

Saarela, J.M.; Rai, H.S.; Doyle, J.A.; Endress, P.K.; Mathews, S.; Marchant, A.D.; Briggs, B. G. \& Graham, S.W. 2007. Hydatellaceae identified as a new branch near the base of the angiosperm phylogenetic tree. Nature 446: 312-315.

Schott, H.W. \& Endlicher, S.L. 1832. Meletemata Botanica. Vol.24. Typis C. Gerold, Vindobonae. $36 \mathrm{p}$.

Schreber, D.J.C.D. 1789. Genera Plantarum Eorumque Characteres Naturales Secundum Numerum, Figuram, Situm, \& Proportionem Omnium Fructificationis Partium. Vol. 39. Frankfurt am Main, Germany. 379p.

Seubert, M. 1855. Mayacaceae. In: Martius, C.P.F. \& Eichler, G.A. Flora Brasiliensis. Frid. Fleisher, Leipzig. Vol. 3, pp. 225-232.

Souza, M.B.G.; Dabés, M.B.G.S. \& Greco, M.K.B. 2001. Comparação da microfauna litorânea, com e sem a presença na macrófita Mayaca sellowiana (Mayacaceae) Ribeirão Passageiro, MG. Bioscience 9: 9-14.

Souza, V.C. \& Lorenzi, H. 2012. Botânica Sistemática $3^{\mathrm{a}}$ Ed. Instituto Plantarum, Nova Odessa. 768p.

Stellfeld, C. 1967. Mayaca madida (Vell.) Stefelld. Tribuna Farmaceutica. 35: 1-2.

Stevens, P. Angiosperm Phylogeny Website. Available at $<$ http://www.mobot.org/mobot/research/apweb $>$. Access on 19 september 2014.

Stevenson, D.W.; Davis, J.I.; Freudenstein, J.V.; Hardy, C.R.; Simmons, M.P. \& Specht, C.D. 2000. A phylogenetic analysis of the monocotyledons based on morphological and molecular character sets, with comments on the placement of Acorus and Hydatellaceae. In: Wilson K. \& Morrison D. Monocots: systematics and evolution. CSIRO, Melbourne. Pp.17-24.

Stevenson, D.W. 1998. Mayacaceae. In: Kubritzki, K. The families and genera of vascular plants. Springer Verlag, Berlin, Pp. 294-296. 
The Plant List 2014. Version 1.1. Available at $<$ www. theplantlist.org >. Access on 13 december 12014.

Thieret, J.W. 1975. The Mayacaceae in the southeastern United States. Journal of the Arnold Arboretum 56: 248-255.

Tomlinson, P.B. 1969. Commelinales-Zingiberales. In: Metcalfe, C.R. Anatomy of Monocotyledons. Vol. 3. Clarendon Press, Oxford. 446p.

Uphof, J.C.T. 1933. Die Blütenbiologie von Mayaca fluviatilis Aubl. Vol. 51. Berichte der Deutschen Botanischen Gesellschaft. Pp. 78-85.

Van Tieghem, P. 1898. Eléments de botanique. Ed. 3. Libraires de L'Académie de Médicine, Paris. 120p.

Vandelli, D. 1788. In: Vandelli, D. Florae Lusitana et Brasilis Species. Lisboa. p. 4, tab.1, fig. 2.
Vellozo, J.M.C. 1827. Florae Fluminensis Icones. Vol.1. Lithogr. Senefelder, Paris. 153p.

Venturelli, M. \& Bouman, F. 1986. Embryology and seed development in Mayaca fluviatilis (Mayacaceae). Acta Botanica Neerlandica 35: 497-516.

Wanderley, M.G. \& Giulietti, A.M. 2002. Mayacaceae In: Wanderley, M.G.; Shepherd, G.J \& Giulietti, A.M. Flora Fanerogâmica do Estado de São Paulo. Vol. 2. HUCITEC, São Paulo. Pp. 185-186.

Warming, E. 1867. Symbolae ad Floram Brasiliae centralis cognoscendam- Partic I-X. Videnskabelige Meddelelser fra den Naturhistoriske Forening i Kjøbenhavn. Copenhagen. 42p.

Willdenow, C.L. 1797. In: Species Plantarum. Vol. 1. Berolini, Berlin. 254p. 